\title{
EDITORIAL
}

\section{UMA NOVA ETAPA DA RBCE}

Esta edição constitui a décima oitava preparada pela equipe que, deste o final de 2007, é responsável por editorar a Revista Brasileira de Ciências do Esporte, processo que ocorre, efetivamente, desde o v. 29, n. 2. Inaugura uma nova etapa dessa caminhada, mas, também, do próprio periódico: é o primeiro número, nos seus 35 anos de existência, a ser publicado apenas no formato eletrônico. As razões desta decisão, tomada em conjunto com a Direção Nacional do Colégio Brasileiro de Ciências do Esporte (CBCE), foram explicitadas no editorial anterior.

No corrente ano teremos mais uma edição do Congresso Brasileiro Ciências do Esporte/Congresso Internacional de Ciências do Esporte, a ser realizado na cidade de Brasília, entre os dias 2 e 7 de agosto. Para a RBCE, essa edição do evento representa uma novidade em seu ciclo de vida. Na verdade, é a retomada de uma prática já realizada em alguns momentos de sua trajetória. Serão publicados, em número especial, sessenta comunicações orais apresentadas nos Grupos de Trabalho Temático (GTT) do Congresso. Essa decisão, entre outras motivações, visa fortalecer o principal evento de nossa entidade científica, incentivando os pesquisadores a submeterem os resultados de suas investigações também na expectativa de uma ulterior publicação na RBCE. É importante destacar que o processo de avaliação, embora respeite as normas de submissão da RBCE, ficará sob a responsabilidade de cada GTT, que indicará para publicação as melhores comunicações orais apresentadas.

A despeito dessas "novidades", alguns desafios permanecem no horizonte da política editorial: profissionalização, financiamento, indexação em bases mais reconhecidas, internacionalização etc. Destaque, neste quesito, a um desafio que acomete ao campo científico e que merece reflexão da RBCE e dos demais periódicos da área: a má conduta acadêmica, representada por ações como plágio, autoplágio, fatiamento da produção científica etc. Já há, no Conselho Nacional de Desenvolvimento Científico e Tecnológico (CNPq), uma comissão de integridade na atividade científica que examina situações em que existem dúvidas fundamentadas quanto à integridade da pesquisa realizada e/ou publicada. Estamos atentos a essa problemática e aos dilemas que apresenta à editoração de periódicos científicos.

Neste número da RBCE, temos dezesseis artigos originais e um de revisão. Os primeiros sete artigos, todos de pesquisadores brasileiros, tratam de diferentes 
temas e objetos de investigação vinculados às áreas biomédicas da Educação Física/ Ciências do Esporte: transtorno do desenvolvimento da coordenação motora de escolares com idade entre 7 e 10 anos, efeito da direção da transferência interlateral no aprendizado de tarefa de toques de dedos em indivíduos adultos, prevalência do uso de suplementos alimentares nas academias da cidade de Porto Alegre, perfil lipídico e glicêmico de ratos treinados, suplementados com maltodextrina, insatisfação com o peso e a massa corporal em estudantes do Ensino Fundamental e Médio do sexo feminino no município do Rio de Janeiro, limiar anaeróbico ventilatório em adolescentes brasileiros de ambos os sexos, associação entre a prática de futebol com fatores sóciodemográficos em escolares na cidade de Aracaju/SE.

O segundo bloco desta edição é composto por nove trabalhos de áreas socioculturais da Educação Física/Ciências do Esporte, incluindo um de uma pesquisadora da Argentina. Eles trazem resultados de pesquisas sobre as seguintes temáticas: o processo de esportivização da prática cultural skate no Brasil entre 1960 e 1990, o tempo no processo de educação das crianças e as implicações para as aulas de Educação Física, o conteúdo das mensagens que colocam a proposta dos jogos cooperativos como superior aos jogos competitivos, especialmente quando se propõe uma educação transformadora em relação aos valores sociais humanos; as formas pelas quais a condição de juventude pode exercer influência nas significações atribuídas, pelos sujeitos em formação inicial, ao ser professor; identificação, junto aos alunos egressos dos Programas de Pós-Graduação Stricto Sensu em Educação Física, das prioridades do processo formativo estabelecidas pela Instituição em que realizaram seus cursos; o associativismo esportivo de mulheres no contexto de um time de futsal feminino; práticas da torcida do Grêmio Esportivo Brasil, da cidade de Pelotas/RS; os processos históricos de longa duração em uma área de estudo particular, que permitiram a configuração das relações entre noções sócio-históricas de corpos, categorizações socioétnicas regionais dominantes e identificações de grupo mais profundas entre os jogadores e simpatizantes do futebol praticado entre os povos Vallistos; a forma como a Igreja Evangélica Assembléia de Deus compõe a educação do corpo das meninas que a frequentam. Fecha esta edição um artigo de revisão que objetiva compilar os principais achados quanto aos efeitos adversos devido à perda rápida de peso em atletas de combate.

Boa leitura!

Florianópolis, Vitória, março de 2013.

Alexandre Fernandez Vaz

Felipe Quintão de Almeida

Jaison José Bassani 